\title{
Establishment of Desmoncus orthacanthos Martius (Arecaceae): effect of inoculation with arbuscular mycorrhizae
}

\author{
José A. Ramos-Zapata ${ }^{1 *}$, Roger Orellana ${ }^{1} \&$ Edith B. Allen ${ }^{2}$ \\ Centro de Investigación Científica de Yucatán A.C., 43 \# 130, CP 97200, Mérida, Yucatán, México. \\ Department of Botany and Plant Sciences, University of California, Riverside, CA 92521-0124. \\ Corresponding author, Present address: Universidad Autónoma de Yucatán. A.P. 4-116, Itzimná, C.P. 97000. Mérida, \\ Yucatán, México. Tel. (052) 99994232 15, Fax. (052) 99994232 05; aramos@tunku.uady.mx
}

Received 11-VIII-2005. Corrected 24-IX-2005. Accepted 10-X-2005.

\begin{abstract}
Inoculation with arbuscular mycorrhizal (AM) fungi has often promoted increased growth of plants but very little work has been done in the tropics to evaluate the effects of inoculation on the establishment and development of seedlings in forests. Desmoncus orthacanthos Martius is a scandent palm present both in early and late succession, and consequentl y can be used in restoration processes. A test was conducted to determine the effect of AM on the establishment of Desmoncus orthacanthos in tropical forest in the Yucatan Peninsula, Mexico. Thirty inoculated and 30 non-inoculated seedlings were introduced in two sites of different successional age, a mature forest and an eight-year old abandoned cornfield (acahual). Survival and growth parameters were evaluated after 12 months. Leaf area and phosphorus, but not height, were greater in inoculated than non-inoculated plants in the forest but not in the acahual. However, mycorrhizae had a clear effect on plant survival in both sites, with a threefold increase in survival of inoculated compared with non-inoculated plants bassed on an odds ratio. The results suggest that inoculation will be important to increase the establishment of this commercially important palm. Rev. Biol. Trop. 54(1): 65-72. Epub 2006 Mar 31.
\end{abstract}

Key words: Arbuscular mycorrhizae, tropical palm, seedlings establishment, tropical forest, abandoned cornfield, acahual.

The establishment of seedlings in the field is a critical stage in tropical reforestation and in the success of plantations. Arbuscular mycorrhizal fungi (AMF) may play an important role in successful reforestation, as inoculation of tree seedlings has actually increased the success of establishment in the field (Mukerji et al. 1991, Allen et al. 2003, 2005). According to Janos (1980), most tree species of mature tropical wet forest are obligate mycorrhizal. However, in oligotrophic environments the pioneer plants also develop AM colonization, which is of great importance for their establishment (Lovera and Cuenca 1996). In well established or mature vegetation, seedlings may connect into a pre-existing network of mycelium of arbuscular mycorrhizae (Simard and Durall 2004) that can provide greater uptake of essential nutrients (Eissenstat and Newman 1990, Pedersen and Sylvia 199, Zobel et al. 1997) and phosphorous in tissues (Joner 2000, Fisher and Jayachandran 2002), a greater resistance to water stress (Augé 2001), protection against pathogens (Varma 1995) and an increased competitive advantage over other seedlings (Grime et al. 1987, Francis and Read 1994, van der Heijden et al. 1998, Guadarrama et al. 2004).

Given the growing degradation of habitats in the tropics, it is necessary to evaluate the role of arbuscular mycorrhizae in the re-introduction and reforestation with seedlings produced in greenhouses, a topic that has received relatively little study (Jagpal and Mukerji 1991, 
Fischer et al. 1994, Lovera and Cuenca 1996, Allen et al. 2003, 2005). The exploitation of non-timber resources in the wet tropical forest located in the Ejido (communally-owned land) Noh Bec, Quintana Roo, México, has generated a growing interest in the use of Desmoncus orthacanthos Martius a palm that grows in abandoned agricultural fields as well as mature forests in the Yucatán Peninsula. Due to the climbing habit of this plant, it produces long, flexible shoots used in the manufacture of handcrafts. However, the utilization of this slow-growing palm will require replanting and management to avoid depletion of wild stocks. This may include the use of individuals initiated in the greenhouse with mycorrhizal inoculum to improve establishment.

Although there is a general understanding of the advantages inoculation with AM provides in tests with transplants, some studies have reported cases in which the plant does not respond positively to inoculation and on occasions may even have a deleterious effect (Castellano 1996). It was not clear from existing literature whether $D$. orthacanthos would respond positively to inoculation, especially given that it is both a colonizing species and a plant of mature forests. The aim of this work is to evaluate the effect of arbuscular mycorrhizae inoculation on the establishment, development and survival of $D$. orthacanthos seedlings in two sites, a mature forest and an abandoned cornfield (acahual).

\section{MATERIAL AND METHODS}

Plant material: Mature fruits of $D$. orthacanthos were collected and seeds were germinated in humid chambers using sterilized agrolite as a substrate. Once germinated, the seedlings were transferred to $500 \mathrm{ml}$ plastic bags filled with $350 \mathrm{ml}$ of steam-sterilized soil and with the addition of $50 \mathrm{ml}$ of inocula depending on the treatment.

Inoculation: For the treatment with mycorrhizae, $50 \mathrm{ml}$ of soil from the mature forest were used for each plant. Soil was collected from the surface $20 \mathrm{~cm}$ in April. The soil used as inoculum was sifted through a $2 \mathrm{~mm}$ grid to allow the passage of fine roots colonized with AMF, spores and extraradical mycelium distributed in the soil. Soil inoculum was used because this is appropriate for a field experiment in native soils (Koide and Li 1989), and has been used successfully previously in seasonal tropical forest (Allen et al. 2003).

The treatment without mycorrhizae was inoculated with $50 \mathrm{ml}$ of steam-sterilized soil and a soil filtrate to re-establish the microbiota of the soil. The soil filtrate was also obtained from soil taken from forest, which was homogenized in distilled water and filtered through a Whatman 42 filter paper to prevent the passage of AMF spores (Azcón and Barea 1997); $50 \mathrm{ml}$ of the filtrate were applied to each plastic growth bag.

Growing conditions: Plants grown in each treatment were placed randomly in a greenhouse for 2 months. When the plants produced two leaves and reached a height of $10 \mathrm{~cm}$, they were transplanted to the two field sites, forest and acahual. Prior to the introduction, the roots were stained using the bleaching and staining technique with Trypan blue (Phillips and Hayman 1970) to determine the percent of mycorrhizal colonization of the seedlings in both treatments.

Establishment in the field: In September 2001, 30 seedlings were introduced in each site (forest and acahual), 15 seedlings inoculated with $\mathrm{AMF}$ and 15 seedlings without inoculation. The mature forest (located at $19^{\circ} 07^{\prime} 28^{\prime \prime} \mathrm{N}$ and $88^{\circ} 20^{\prime} 25^{\prime \prime} \mathrm{W}$ ), is a mediumheight, sub-perennial forest undisturbed by human activities for the last $80-100$ years. The abandoned cornfield (located at $19^{\circ} 05^{\prime} 54^{\prime \prime}$ $\mathrm{N}$ and $88^{\circ} 13^{\prime} 30^{\prime \prime} \mathrm{W}$ ), is secondary vegetation, or acahual, generated from abandoned slash and burn local agriculture, where the original vegetation had been burned for the last time 10 years ago, and abandoned from agriculture eight years ago. The vegetation present in each of the sites under study shows contrasts 
in composition and average height. Seedlings were planted randomly near the center of gaps larger than $3 \mathrm{~m}$ diameter, with a $1 \mathrm{~m}$ distance between one mycorrhizal and one non-mycorrhizal seedling in each gap.

Parameters evaluated: Root samples from seedlings were taken from the greenhouse prior to transplanting $(\mathrm{n}=20)$. Survival was evaluated 12 months after the introduction of the seedlings, also values of height and leaf area was carried out. Samples of the youngest fully-expanded leaf of each palm were taken to evaluate the leaf phosphorous concentration using the technique of digestion in $\mathrm{HNO}_{3} /$ $\mathrm{HClO}_{4}$ (Houba et al. 1988).

Soil analysis: Several soil characteristics of the forest and abandoned cornfield were evaluated. Extractable phosphorus was determined according to Olsen and Dean (1965), and Kjeldahl semi-micro total nitrogen (Bremmer 1965 ) as well as $\mathrm{pH}$ value in soil solution.

To evaluate the infective capacity of the soil in both communities, samples were taken and the mycorrhizal-forming units were determined using the most probable number test (MPN) of AM propagules; following a fourfold soil dilution series (Porter 1979), Sorghum vulgare L. was used as a trap plant, with four replicates of each dilution.

Statistical analysis: Values of total height, leaf area, concentration of leaf $\mathrm{P}$, were tested using a two way analysis of variance (ANOVA), in order to compare the effect of the treatments (with and without AM fungi) in the sites (forest and acahual). To detect differences between the values, a Student-NewmanKeuls multiple comparison test was applied. The effect of the treatments on survival was evaluated with a multiple binomial linear regression analysis and the reason of advantage was calculated (odds ratio) (Zar 1999).

\section{RESULTS}

The chemical and biological characteristics of the soil varied between the two study sites (Table 1). The number of AMF propagules was greater in acahual than mature forest, while extractable $\mathrm{P}$ and total $\mathrm{N}$ were greater in forest than acahual. The $\mathrm{pH}$ was not different.

TABLE 1

Chemical and biological characteristics of the soils from the study areas

\begin{tabular}{lcc}
\multicolumn{1}{c}{ Soil parameters } & Forest & Acahual \\
P available $^{\text {a }}\left(\mathrm{mg} \mathrm{kg}^{-1}\right.$ soil $)$ & 18.80 & 13.50 \\
Total $^{\mathbf{b}}\left(\mathrm{cmol} \mathrm{kg}^{-1}\right.$ soil $)$ & 67.75 & 16.93 \\
${\text { Soil } \mathrm{pH}^{\mathbf{c}}}$ & 7.3 & 7.1 \\
$\begin{array}{l}\text { Propagules of AMF } \\
\left(50 \mathrm{~mL}^{-1} \text { soil }\right)\end{array}$ & 4.5 & 18 \\
& & \\
a: Olsen P extractable. & & \\
b: Semi-micro-Kjeldahl. & & \\
c: Soil solution. & & \\
d: MPN (Porter 1979). & &
\end{tabular}

The highest value of leaf area in seedlings was registered in the AM treatment introduced in the forest. The value of leaf area (Fig. 1) indicates significant differences between the treatments with inoculation (Table 2), with higher values of leaf area in the seedlings with the inoculation treatment for both sites. The interaction between the inoculation and the site of establishment was also significantly different.

The acahual site showed the highest values for seedling height. Significant statistical differences were found between the areas of establishment, but there was no significant difference between inoculum treatments (Table 2).

The highest value of tissue $\mathrm{P}$ concentration was found in seedlings inoculated with AM and introduced in the forest (Figure 2). This was statistically different from the values found for 


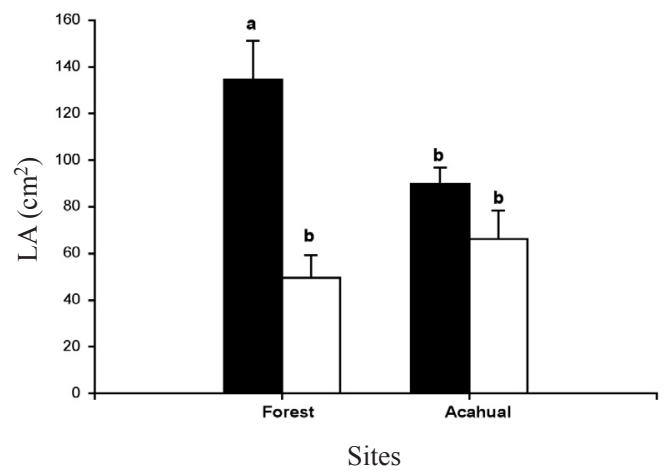

Fig. 1. Average leaf area (+1S.E.) of the seedlings, one year after introduction in the different environments and with different treatments. The dark bars represent the treatment with mycorrhizae; the open bars represent treatment without mycorrhizae. The bars marked with the same letter show no significant differences $(n=8)$.

TABLE 2

$F$ values of the ANOVA of the parameters evaluated. $L A=$ leaf area, $H=$ height, $P t=$ concentration of leaf $P$. (n.s. $=$ not significant, $* p<0.05, * * p<0.01, * * * p<0.001$ )

$\begin{array}{lccc}\begin{array}{c}\text { Source } \\ \text { of variation }\end{array} & \begin{array}{c}\text { LA } \\ (\mathrm{n}=8)\end{array} & \begin{array}{c}\mathrm{H} \\ (\mathrm{n}=8)\end{array} & \begin{array}{c}\mathrm{Pt} \\ (\mathrm{n}=5)\end{array} \\ \text { Inoculation } & 20.64 * * * & 1.11 \text { n.s. } & 278.3 * * * \\ \text { Site } & 1.37 \text { n.s. } & 8.72 * * & 152.0 * * * \\ \text { Inoculation x Site } & 6.50 * & 0.29 \text { n.s. } & 254.8 * * *\end{array}$

the other treatments both for forest and acahual. The $\mathrm{P}$ values showed a statistical interaction for inoculation and site (Table 2).

The survival of plants introduced to the field was different depending on the inoculum treatment, when the odds ratio was calculated, plants inoculated with AM had a probability of survival three times higher than the plants without inoculation (Table 3).

\section{DISCUSSION}

The establishment of seedlings is one of the most important stages for the maintenance and recovery of populations of plant species (Eriksson 1989), and establishment has been

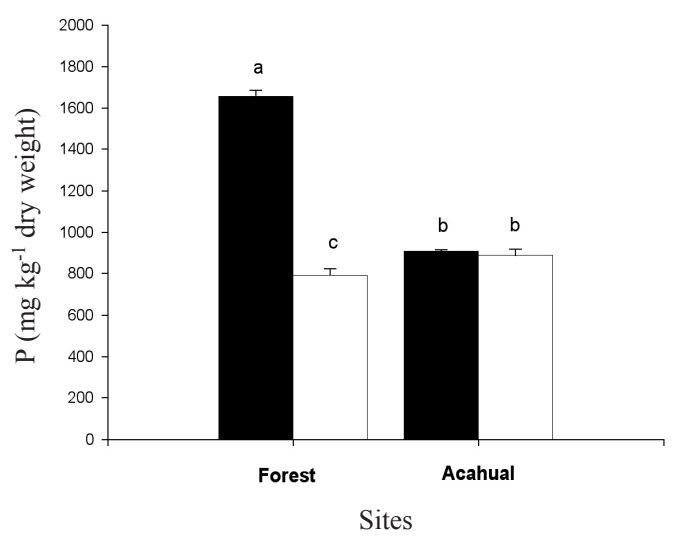

Fig. 2. Average leaf content of phosphorous (+1S.E.) in the seedlings, one year after introduction in the different environments and with different treatments. The dark bars represent the treatment with mycorrhizae; the open bars represent treatment without mycorrhizae. The bars marked with the same letter show no significant differences $(n=5)$.

TABLE 3

Odds ratio calculated for the effect of the sites and treatments on survival $(n=60)$

\begin{tabular}{lcccc}
\multicolumn{1}{c}{ Parameter } & Odds ratio & $\begin{array}{c}\text { Upper } \\
\text { limit }\end{array}$ & $\begin{array}{c}\text { Lower } \\
\text { limit }\end{array}$ & $\mathrm{p}$ \\
Sites & 0.405 & 1.359 & 0.121 & 0.143 \\
Treatments & 3.493 & 11.995 & 1.017 & 0.047
\end{tabular}

observed in the field for this species (EscalanteRebolledo et al. 2004). Competition between established vegetation and the seedlings in their proximity is one of the greatest biotic forces determining the structure of a plant community (Kytoviita et al. 2003). If we consider the integration of the seedlings in an existing network of AM mycelium of relevance, then the study of the establishment of seedlings inoculated with AM fungi is of prime interest (Zobel et al. 1997).

According to Mosse and Hayman (1980), colonization of the roots with AM prior to the introduction of seedlings to the field provides the plant with advantages for establishment. Prior to transplanting seedlings, the inoculum density should be evaluated to determine the 
relative importance or necessity of inoculation. According to Gianinazzi et al. (1989), when high values of infective native propagules are found in the soil, the process of inoculation is unnecessary. However, not only the number of propagules, but also the effectiveness in the formation of new units of infection must be taken into consideration (Klironomos and Hart 2002). Furthermore, the colonization process may take time, and pre-inoculated seedlings may have an advantage even in soils with high inoculum density, as was demonstrated by transplanting inoculated and uninoculated seedlings in a seasonal tropical forest (Allen et al. 2003). Inoculation in the greenhouse ensured that the seedlings introduced to the field had colonization before transplanting, providing them with an advantage over the plants without inoculation, which was evident in this study in increased leaf area and survival.

The majority of studies carried out on inoculation have demonstrated the superiority of mycorrhizal over non-mycorrhizal plants in aspects such as greater survival and initial growth in reforested areas (Mukerji et al. 1991). The results obtained in this study agree with this, showing increased survival of the inoculated seedlings introduced in the study sites. According to the analysis these seedlings present an advantage three times greater in comparison with seedlings without inoculation, this coincides with observations made by Estaún et al. (1997) and Azcón-Aguilar et al. (2003) who have confirmed that AM fungi (AMF) inoculation increases the probability of establishment in disturbed areas.

The abandoned cornfield is characterized by a large number of seedlings in contrast to the low density of seedlings observed in the mature forest, where a high mortality rate is also observed as well as consumption of the seedlings by herbivores (personal observations). The effect of inoculation on the rate of survival for seedlings introduced in the undisturbed site is evident, which highlights the potentially important role the association with AMF plays in the successful establishment of the seedlings. It is interesting to note that the effect of inoculation on survival can be observed in an early stage of establishment in this perennial species, which coincides with previous reports on the positive effect of inoculation on the establishment of seedlings in the field (Francis and Read 1994, Pedersen and Sylvia 1996, Varma 1995, Fisher and Jayachandran 2002, Azcón-Aguilar et al. 2003). The analysis of results obtained in this study allow us to coincide with Siqueira and Saggin-Júnior (2001) to the effect that, in the tropics, the seedlings must be inoculated with AM prior to introduction in the field in order to increase survival and initial growth.

Although mycorrhizal inoculation caused increased survival in both sites, effects on plant growth were different. In mature forest mycorrhizae promoted increased leaf $\mathrm{P}$, but not in acahual. Increased $\mathrm{P}$ uptake by mycorrhizae has been noted in other species (Al-Karaki 2002) including tropical forest trees (Bâ et al. 2000, Whitbeck 2001). However, in another study six species of tropical forest trees had no increase in leaf $\mathrm{P}$ concentration following inoculation and transplanting to the field, although they did have increased height and survival (Allen et al. 2003). The different responses by D. orthacanthos in this study may be related to the different sites. The forest soil had higher extractable $\mathrm{P}$ and would not be expected to have a greater response of leaf $\mathrm{P}$ to inoculation, but the forest seedlings also had a greater leaf area. The leaf area response may be due to greater shading, as the forest site has taller trees and therefore more shade than acahual.

The leaf $\mathrm{P}$ concentration in seedlings without AM inoculation were different among the acahual and forest, the value was higher in acahual, this differences may be due the difference in the number of infective propagules (Table 1) and in the composition of the community of AM, since the contribution of phosphorous from the native AM depends on the abundance of the propagules and on their effectiveness in the transfers of $\mathrm{P}$ from soil to plant (Solaiman and Abbot 2003). Mature seasonal tropical forest has a greater diversity of AM spore species than acahual, and includes a higher 
density of species in the genera Gigaspora and Scutellospora (Allen et al. 2003). In another study, plants inoculated with Scutellospora had less efficient $\mathrm{P}$ uptake and lower growth rates than those with Glomus (Pearson and Jacobson 1993). This is the first work on inoculation and introduction of a palm species in the Mexican tropics, it was found that the establishment in the field of $D$. orthacanthos seedlings was favored by AM inoculation. Although after six monsth mycorrhizal colonization was low (ca. 5\% root colonized, data does not showed), the results suggest that inoculation prior to plant introduction to the field is important to increase survival and growth, and that the degree of plant response will depend upon the field site. Other researchers in the tropics have also shown beneficial responses of inoculated, transplanted seedlings (Fischer et al. 1994, Siqueira and Saggin-Júnior 2001, Allen et al. 2003, 2005), suggesting that inoculation should be part of a program for the reintroduction of the useful palm $D$. orthacanthos to increase its abundance for future harvesting.

\section{ACKNOWLEDGMENTS}

We thank to Patricia Guadarrama for her comments on an earlier draft of this manuscript, we also want to thank to Lilia Carrillo, Joaquin Quiróz and Roberto Sibaja for helping in field and laboratory work. J.R.Z. got a doctoral grant (153737) from the Consejo Nacional de Ciencia y Tecnología (CONACYT).

\section{RESUMEN}

La inoculación con hongos micorrizógenos arbusculares (AM) promueve un incremento en el crecimiento de las plantas, sin embargo poco trabajo se ha realizado en los trópicos para evaluar el efecto de la inoculación en el proceso de establecimiento de plántulas. Desmoncus orthacanthos Martius es una palmera trepadora que se distribuye tanto en etapas tempranas y tardías de la sucesión, por lo tanto puede ser empleada en procesos de restauración. Se realizó una prueba de establecimiento de D. orthacanthos en una selva tropical de la península de Yucatán, México. Treinta plántulas inoculadas y 30 no inoculadas se establecieron en dos sitios con diferentes etapas sucesionales: selva madura y un campo abandonado de maíz (acahual). Después de 12 meses el valor de área foliar y contenido de fósforo fue mayor en el tratamiento con micorrizas en la selva pero no en el acahual, sin embargo, el tratamiento con micorrizas mostró un claro efecto en la supervivencia de las palmeras en ambos sitios con un incremento tres veces mayor en la probabilidad de supervivencia de palmeras inoculadas comparadas con las no inoculadas de acuerdo al análisis de razón de disparidad (odds ratio). La inoculación podría ser importante para incrementar el establecimiento de esta palmera.

Palabras clave: Micorriza arbuscular, palmera tropical, establecimiento de plántulas, selva tropical, cultivo de maíz abandonado, acahual.

\section{REFERENCES}

Al-Karaki G.N. 2002. Benefit, cost, and phosphorus use efficency of mycorrhizal field-grown garlic at different soil phosphorus levels. J. Plant Nutr. 25: 1175-1184.

Allen, E. B., M.F. Allen, L. Egerton-Warburton, L. Corkidi \& A. Gomez-Pompa. 2003. Impacts of early and late seral mycorrhizae during restoration in seasonal tropical forest, Mexico. Ecol. Appl. 13: 1701-1717.

Allen, M.F., E.B. Allen \& A. Gomez-Pompa. 2005. Effects of mycorrhizae and nontarget organisms on restoration of a seasonal tropical forest in Quintana Roo, Mexico: factors limiting tree establishment. Restor. Ecol. 13: 325-333.

Augé, R.M. 2001. Water relations, drought and vesiculararbuscular mycorrhizal symbiosis. Mycorrhiza 11: $3-42$.

Azcón-Aguilar C., J. Palenzuela, A. Roldán, S. Bautista, R. Vallejo \& J.M. Barea. 2003. Analysis of the mycorrhizal potential in the rhizosphere of representative plant species from desertification-threatened Mediterranean shrublands. Appl. Soil Ecol. 22: 29-37.

Bâ, A.M., C. Plenchete, P. Danthu, R. Duponnois \& T. Guissou. 2000. Functional compatibility of two arbuscular mycorrhizae with thirteen fruit trees in Senegal. Agroforest. Syst. 50: 95-105.

Bremmer, J.M. 1965. Total nitrogen, p. 1149-1178. In C.A. Black (ed.). Methods of soil analysis. American Society of Agronomy. Madison, Wisconsin, USA.

Castellano, M.A. 1996. Outplanting performance of mycorrhizal inoculated seedling, p. 223-301. In K. Mukerji (ed.). Concepts in Mycorrhizal Research, Kluwer, Dordrecht, The Netherlands. 
Eissenstat, D.M. \& E.I. Newman. 1990. Seedling establishment near large plants: effects of vesicular-arbuscular mycorrhizas on intensity of plant competition. Funct. Ecol. 4: 95-99.

Eriksson, O. 1989. Seedling dynamics and life histories in clonal plants. Oikos 55: 231-238.

Escalante, S., C. Montaña \& R. Orellana, 2004. Demography and potential extractive use of the liana palm Desmoncus orthacanthos Martius (Arecaceae), in Southern Quintana Roo, México. Forest Ecol. Manag. 187: 3-18.

Estaún, V., R. Savé \& C. Biel. 1997. AM inoculation as a biological tool to improve plant revegetation of a disturbed soil with Rosmarinus officinalis under semiarid conditions. Appl. Soil Ecol. 6: 223-229.

Fischer, C.R., D.P. Janos, D.A. Perry, R.G. Linderman \& P. Sollins. 1994. Mycorrhiza inoculum potentials in tropical secondary succession. Biotropica 26: 369-377.

Fisher, J.B. \& K. Jayachandran. 2002. Arbuscular mycorrhizal fungi enhance seedling growth in two endangered plant species from south Florida. Int. J. Plant Sci. 163: 559-566.

Francis, R. \& D.J. Read. 1994. The contribution of mycorrhizal fungi to the determination of plant community structure. Plant Soil. 159: 11-25.

Gange, A.C., V.K. Brown \& G.S. Sinclair. 1993. Vesiculararbuscular mycorrhizal fungi: a determinant of plant community structure in early succession. Funct. Ecol. 7: 616-622.

Gianinazzi, S., A. Trouvelot \& V. Gianinazzi-Pearson. 1989. Conceptual approaches for the rational use of VA endomycorrhizae in agriculture: possibilities and limitations. Agr. Ecosyst. Environ. 29: 153-161.

Grime, J.P., J.M. Mackey, S.H. Hillier \& D.J. Read. 1987. Floristic diversity in a model system using experimental microcosms. Nature 328: 420-422.

Guadarrama P., J. Álvarez-Sánchez \& O. Briones. 2004. Seedling growth of two pioneer tropical tree species in Competition: The role of arbuscular mycorrhizae. Euphytica 138: 113-121.

Houba, V.J.G., J.J. Van Der Lee, I. Novozamsky \& I. Walinga. 1988. Soil and plant analysis. Part 5. Soil analysis procedures. Wageningen Agricultural University, Department of Soil Science and Plant Nutrition, Wageningen, The Netherlands. 56 p.

Jagpal, R. \& K.G. Mukerji. 1991. VAM fungi in reforestation, p. 309-313. In B.L. McMichael \& H Persson (eds.). Plant roots and their environment.
Development in Agricultural and Managed-Forest Ecology. Elsevier, Amsterdam, The Netherlands.

Janos, D.P. 1980. Vesicular arbuscular mycorrhizae affect lowland tropical rain forest plant growth. Ecology 61: $151-162$

Joner, E.J. 2000. The effect of long-term fertilization with organic or inorganic fertilizers on mycorrhiza-mediated phosphorus uptake in subterranean clover. Biol. Fert. Soils. 32: 435-440.

Koide, R.T. \& M. Li. 1989. Appropriates controls for vesicular-arbuscular mycorrhiza research. New Phytol. 111: $35-44$

Kytoviita, M.M, M. Vestberg \& J. Tuomi. 2003. A test of mutual aid in common mycorrhizal networks: established vegetation negates benefits in seedlings. Ecology 84: 898-906.

Lovera, M. \& G. Cuenca. 1996. Arbuscular mycorrhizal infection in Cyperaceae and Gramineae from natural, disturbed and restored savannas in La Gran Sabana, Venezuela. Mycorrhiza 6: 111-118.

McGonigle, T., M.H.Miller, D.G.Evans, G.L. Fairchild \& J.A. Swan. 1990. A new method which gives an objective measure of colonization of roots by vesicular-arbuscular mycorrhizal fungi. New Phytol. 115: 495-501.

Mosse, B. \& D.S. Hayman. 1980. Mycorrhiza in tropical plants, p. 213-230. In P. Mikola (ed.). Tropical Mycorrhiza research. Clarendon, Oxford, U.K

Mukerji, K.G., R. Jagpal, M. Bali \& R. Rani. 1991. The importance of mycorrhiza for roots, p. 290-308. In B.L. McMichael \& H. Persson (eds.). Plant roots and their environment, Elsevier, Amsterdam, The Netherlands.

Olsen, S.R. \& L.A. Dean. 1965. Phosphorus, p. 1035-1049. In C.A. Black (ed.). Methods of soil analysis. American Society of Agronomy, Madison, Wisconsin, USA.

Pearson, J. N. \& I. Jakobsen. 1993. The relative contribution of hyphae and roots to phosphorus uptake by arbuscular mycorrhizal plants, measured by dual labelling with phosphorus-32 and phosphorus-33. New Phytol. 124: 489-494.

Pedersen, C. \& D.M. Sylvia. 1996. Mycorrhiza: ecological implications of plant interactions, p. 223-301. In K. Mukerji (ed.). Concepts in Mycorrhizal Research, Kluwer, Dordrecht, The Netherlands.

Phillips, J. \& D. Hayman. 1970. Improved procedures for clearing roots and staining parasitic and vesiculararbuscular mycorrhizal fungi for rapid assesment of infection. Trans. Brit. Myc. Soc. 55: 158-160. 
Porter, W.M. 1979. The "most probable number" method for ennumerating infective propagules of vesiculararbuscular mycorrhizal fungi in soil. Aus. J. Soil Res. 17: $515-519$.

Simard, S.W. \& D.M. Durall. 2004. Mycorrhizal networks: a review of their extent, function, and importance. Can. J. Bot. 82: 1140-1165.

Siqueira, J.O. \& O.J. Saggin-Júnior. 2001. Dependency on arbuscular mycorrhizal fungi and responsiveness of some Brazilian native woody species. Mycorrhiza 11: $245-255$.

Solaiman, M.Z. \& L.K. Abbott. 2003. Phosphorus uptake by a community of arbuscular mycorrhizal fungi in jarrah forest. Plant Soil. 248: 313-320.

Varma, A. 1995. Ecophysiology and application of arbuscular mycorrhizal fungi in arid soils, p. 561-591. In
A.Varma \& B. Hock (eds.). Mycorrhiza. Springer, Berlin, Germany.

van der Heijden, M.G.A., J.N. Klironomos, M. Ursic, P. Moutoglis, T. Streitwolf-Engel, T. Boller, A. Iemken \& I.R. Sanders. 1998. Mycorrhizal fungal diversity determines plant biodiversity, ecosystem variability and productivity. Nature 396: 69-72.

Whitbeck, J.L. 2001. Effects of light environment on vesicular-arbuscular mycorrhiza development in Inga leiocalycina, a tropical wet forest tree. Biotropica 33: 303-311.

Zar, J. 1999. Biostatistical analysis. Prentice Hall, New Jersey, USA

Zobel, M., M. Moora \& E. Haukioja. 1997. Plant coexistence in the interactive environment: arbuscular mycorrhiza should not be out of mind. Oikos 78: 202-208. 